\title{
,awe \\ Good Practices in Sponge Natural Product Studies: Revising Vouchers with Isomalabaricane Triterpenes
}

\author{
Paco Cárdenas ${ }^{1, *(\mathbb{D}}$, Jayani Gamage ${ }^{1,2}\left(\mathbb{D}\right.$, Chamari M. Hettiarachchi ${ }^{2}\left(\mathbb{C}\right.$ and Sunithi Gunasekera ${ }^{1}(\mathbb{D})$ \\ 1 Pharmacognosy, Department of Pharmaceutical Biosciences, Uppsala University, Husargatan 3, \\ 75123 Uppsala, Sweden; jayani_gamage@ymail.com (J.G.); sunithi.gunasekera@farmbio.uu.se (S.G.) \\ 2 Department of Chemistry, University of Colombo, Kumaratunga Munidasa Mawatha, Colombo 03, Sri Lanka; \\ chamarih@chem.cmb.ac.lk \\ * Correspondence: paco.cardenas@farmbio.uu.se
}

check for

updates

Citation: Cárdenas, P.; Gamage, J.; Hettiarachchi, C.M.; Gunasekera, S. Good Practices in Sponge Natural Product Studies: Revising Vouchers with Isomalabaricane Triterpenes. Mar. Drugs 2022, 20, 190. https:// doi.org/10.3390/md20030190

Academic Editors: Micha Ilan, Shmuel Carmeli, Michelle Kelly and Mark T. Hamann

Received: 20 February 2022

Accepted: 2 March 2022

Published: 4 March 2022

Publisher's Note: MDPI stays neutral with regard to jurisdictional claims in published maps and institutional affiliations.

Copyright: (c) 2022 by the authors Licensee MDPI, Basel, Switzerland. This article is an open access article distributed under the terms and conditions of the Creative Commons Attribution (CC BY) license (https:// creativecommons.org/licenses/by/ $4.0 /)$.

\begin{abstract}
Species misidentification in the field of natural products is an acknowledged problem. These errors are especially widespread in sponge studies, albeit rarely assessed and documented. As a case study, we aim to revisit reports of isomalabaricane triterpenes, isolated from four demosponge genera: Jaspis, Geodia, Stelletta and Rhabdastrella. From a total of 44 articles (1981-2022), 27 unique vouchers were listed, 21 of which were accessed and re-examined here: 11 (52.4\%) of these were misidentified. Overall, $65.9 \%$ of the studies published an incorrect species name: previously identified Jaspis and Stelletta species were all in fact Rhabdastrella globostellata. We conclude that isomalabaricane triterpenes were isolated from only two Rhabdastrella species and possibly one Geodia species. In addition to shedding a new light on the distribution of isomalabaricane triterpenes, this study is an opportunity to highlight the crucial importance of vouchers in natural product studies. Doing so, we discuss the impact of species misidentification and poor accessibility of vouchers in the field of sponge natural products. We advocate for stricter voucher guidelines in natural product journals and propose a common protocol of good practice, in the hope of reducing misidentifications in sponge studies, ensure reproducibility of studies, and facilitate follow-up work on the original material.
\end{abstract}

Keywords: Porifera; chemotaxonomy; isomalabaricane triterpenes; vouchers; misidentification; Rhabdastrella globostellata

\section{Introduction}

The necessity of publishing natural product (NP) studies with the right species name is obvious to any researcher, not just as a requirement of reproducibility, but also to make these studies trustworthy sources of data for other fields. However, previous articles have repeatedly felt the need to put forward the importance of taxonomy for NP studies [1] and expressed concerns about misidentification in the NP literature, whether it be plants $[2,3]$ or sponges [4,5], one of the primary sources of new marine natural products [6]. Indeed, identification errors are acknowledged and especially widespread in sponge natural product studies, albeit rarely assessed and documented. Van Soest et al. (1996) [7] is the only study that tried to solve a sponge chemotaxonomy problem by re-examining several NP vouchers, essentially from studies from the 1980s-1990s. As expected, they found several misidentifications. Fortunately, because some of the authors were the original identifiers of several of these vouchers, they could easily access most vouchers; they do however mention that they could not access a few others. Indeed, now that most NP studies have made a habit of keeping a voucher and including a voucher number in their publications, one remaining issue is the poor accessibility and curation of vouchers (P.C., personal experience). Open and easy accessibility is an obvious requirement to serve the purpose of the voucher, even more so when considered in the context of the FAIR principles (Findable, Accessible, Interoperable, Reusable) for the management and sharing of data [8]. This study 
will assess voucher accessibility in sponge NP studies, using chemotaxonomy issues raised by isomalabaricane triterpenes (ITTs) as a test case.

ITTs are tricyclic terpenoids discovered in marine sponges by Ravi et al. (1981) [9]. Forty years later, dozens of studies have contributed to enrich this unique large family of sponge compounds, with more than 160 different structures, usually subdivided into three groups: stellettins (mainly with $\delta$-lactone ring or carboxyl in side chain), stelliferins (oxygenated side chains) and globostellatic acids (carboxylation at C-4) (Figure 1), many of which have significant cytotoxic activities [10,11]. For example, stellettin B (Figure 1) is one of those promising compounds with high antitumor activities [12-15]. One of the richest species in terms of ITTs is undeniably the demosponge Rhabdastrella globostelletta (Carter, 1883) [16], present throughout the Indo-Pacific region [17] in shallow-water coral reef environments. Extracts of its yellow internal pigments led to the discovery of rhabdastrellic acid-A ( $=E$ isomer of stellettin $G$ ) and globostellatic acids [18,19]. So far, ITTs have been isolated from a handful of demosponge species belonging to four demosponge genera belonging to the Astrophorina suborder: Jaspis, Geodia, Stelletta and Rhabdastrella [11]. The odd distribution of ITTs in only a few species from four different species-rich genera with similar skeletons raises the possibility of misidentification. Indeed, demosponge species identification often relies on the categories and morphology of siliceous elements, called 'spicules', that make up the skeleton [20]. Considering the similar spicule assemblages of Jaspis, Geodia, Stelletta and Rhabdastrella (Figure 2), failure to observe one spicule category may easily lead to a wrong genus assignation (Figure 2), consequently leading to a wrong identification of the species. To make matters worse, secondary spicule losses through environmental conditions [21-23] or evolution [24] can easily mislead the identifier. Previous works have tried to solve small pieces of the taxonomic confusions in connection with $R$. globostellata and ITTs [25,26] but a complete and updated revision of the NP literature is required to verify the origin of these compounds. The aims of this study were to (i) revise the taxonomy of voucher specimens used in previous sponge NP studies on ITTs; and therefore (ii) revise the ITT diversity of these species, while (iii) assessing misidentification and voucher accessibility of these studies. Overall, this study is an opportunity to show in practice the crucial importance of vouchers in NP studies, and their accessibility status long after these studies are published. This is followed by a discussion on practices of sponge voucher handling and deposition, and possible ways to improve accessibility of these vouchers. 
<smiles>CC(=CC=CC(C)=C1C(=O)CC2C1(C)CCC1C(C)(C)C(=O)CC[C@]12C)c1ccc(C)c(=O)o1</smiles><smiles>CC(=O)O[C@H]1CC[C@]2(C)C3CC(=O)/C(=C(C)/C=C/C=C(\C)C(O)CC=C(C)C)[C@@]3(C)CC[C@@H]2C1(C)C</smiles>

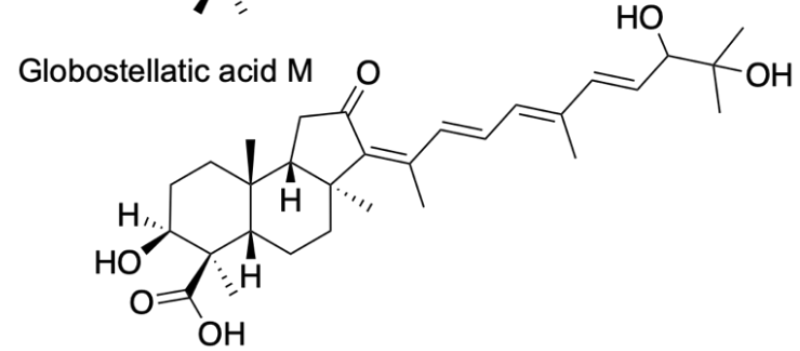

Figure 1. Examples of isomalabaricane triterpenes, often distributed in three groups: stellettins, stelliferins and globostellatic acids.

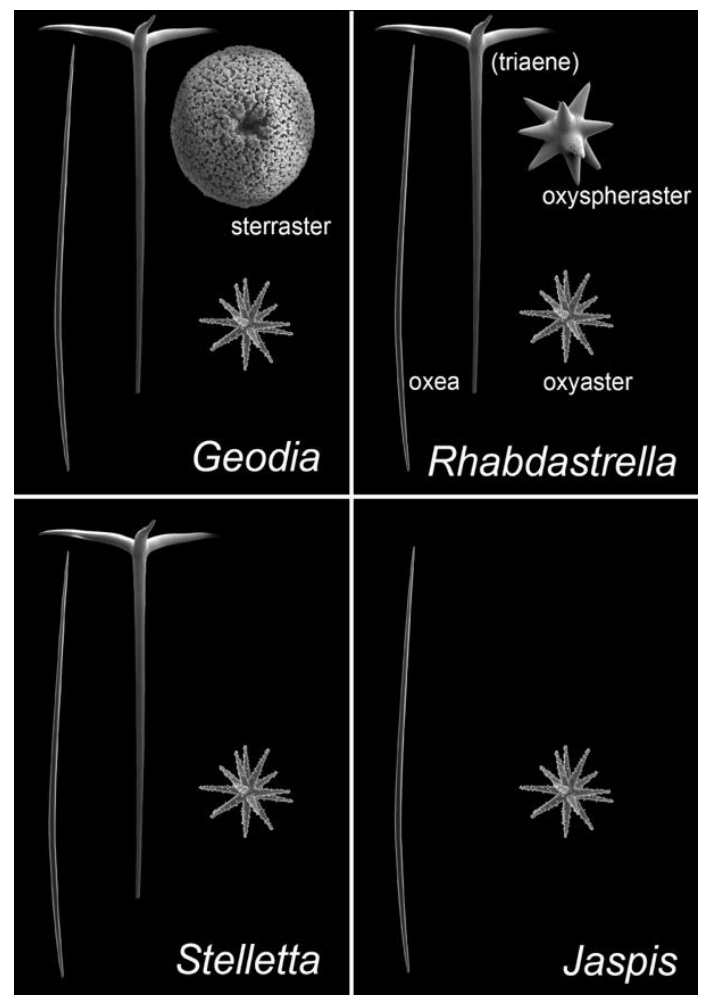

Figure 2. Comparison of siliceous spicule assemblages of demosponge genera in which isomalabaricane triterpenes have been reported: Jaspis, Geodia, Stelletta and Rhabdastrella. Names of the spicule types are given; 'triaenes' can be absent in some species and populations of Rhabdastrella so the term is in parentheses. Spicule pictures (taken with a scanning electron microscope) are representative of spicule types, they are here duplicated for pedagogical purposes; they are also not represented at the same scale. 


\section{Results}

\subsection{Revision of Vouchers}

Table S1 lists relevant details of all 44 NP studies (1981-2022) on sponge ITTs as of January 2022, including 43 articles and one PhD thesis. Table S1 shows the compounds identified, the taxonomist who identified the material (when specified), the locality of the voucher, descriptive details about the voucher (from the article), the voucher number and where it is deposited, along with our revised identifications based on our examination and comparative material, and occasionally based on other taxonomists and/or the literature. Pictures of vouchers (external morphology and/or spicules) were added. For an easier overview and discussion of the results, Table 1 summarizes the information from Table S1. Of the 44 studies, seven do not have any vouchers. Lai et al. [27] report a voucher \#20171221-SP but after examination we discovered that this voucher was actually not from the specimen studied. Indeed, a neighboring specimen, from a different species, was mistakenly photographed and collected as a voucher (K-H Lai, pers. comm.) so there is also no voucher for this study. Within the remaining 36 studies with vouchers, eight vouchers were used for two to three consecutive articles (Table S1), so in the end 26 unique vouchers were recorded. A total of 21 vouchers were re-examined for this study, some illustrated in Figure 3: 16 vouchers were received at Uppsala University (Sweden). We were sent pictures of specimens and/or spicule preparations for another five vouchers (Table S1). Five vouchers, all from Hainan Island, China, could not be re-examined: Geodia japonica [28], Stelletta tenuis $[29,30]$ and Jaspis stellifera [31,32]. It is believed the voucher of G. japonica is lost: it was kept at the 'Research Center of Organic Natural Products Chemistry, Sun Yat-Sen University, Guangzhou, China' which is now closed (Prof Jun Xu, pers. comm.). The S. tenuis voucher from Su et al. [29] was stored at the 'Research Center of Organic Natural Products, Zhongshan University, Guangzhou, China', but we were unable to locate this center. As for the three other vouchers, the authors could not locate the material or could not find information/contacts about the institutes holding the vouchers. Of the 16 vouchers received, six were spicule preparations (all from the Naturalis Museum, Leiden, The Netherlands), nine were subsamples in $\mathrm{EtOH}$ or dried after EtOH extraction and one was from grinded powder (from the Muséum National d'Histoire Naturelle, Paris, France). Importantly, three NP studies out of 44 described the voucher in sufficient detail (external morphology and spicule measurements) so that we could confidently confirm [33,34] or revise [35] the identification before even seeing the voucher. 
Table 1. Revision of Rhabdastrella/Geodia/Stelletta/Jaspis vouchers from natural product articles on isomalabaricane triterpenes. Studies using the same voucher are grouped together. Y/Yes; N/No; -/not applicable. For more details, see Table S1.

\begin{tabular}{|c|c|c|c|c|c|c|c|c|}
\hline Ref. & Identifier & $\begin{array}{c}\text { Description of Voucher } \\
\text { 1. Picture } \\
\text { 2. Color } \\
\text { 3. Spicules } \\
\text { 4. Barcodes } \\
\end{array}$ & $\begin{array}{l}\text { Voucher } \\
(\mathrm{Y} / \mathrm{N})\end{array}$ & $\begin{array}{l}\text { Voucher in } \\
\text { Museum } \\
\text { (Y/N/-) }\end{array}$ & $\begin{array}{c}\text { Voucher } \\
\text { Accessed } \\
(\mathrm{Y} / \mathrm{N} /-)\end{array}$ & $\begin{array}{c}\text { Source } \\
\text { Original ID }\end{array}$ & $\begin{array}{c}\text { Source } \\
\text { Revised ID }\end{array}$ & $\begin{array}{l}\text { Misidentification } \\
\text { (Y/N/?) }\end{array}$ \\
\hline Ravi et al. (1981) [9] & - & 2 & $\mathrm{~N}$ & - & - & J. stellifera & R. globostellata & $\mathrm{Y}$ \\
\hline Ravi \& Wells (1982) [36] & - & - & $\mathrm{N}$ & - & - & J. stellifera & R. globostellata & $\mathrm{Y}$ \\
\hline McCabe et al. (1982) [37] & Bergquist & 2 & $\mathrm{~N}$ & - & - & Stelletta sp. & Rhabdastrella? & Y \\
\hline Su et al. (1994) [29] & JH. Li & - & $\mathrm{Y}$ & $\mathrm{N}$ & $\mathrm{N}$ & S. tenuis & R. globostellata & $\mathrm{Y}$ \\
\hline $\begin{array}{l}\text { Ryu et al. (1996) [18], } \\
\text { Oku et al. (2000) [39] }\end{array}$ & Van Soest & - & $\mathrm{Y}$ & Y & $\mathrm{Y}$ & S. globostellata & R. globostellata & $\mathrm{N}$ \\
\hline Kobayashi et al. (1996) [40] & Fromont & 2 & $\mathrm{~N}$ & - & - & J. stellifera & R. globostellata & $\mathrm{Y}$ \\
\hline $\begin{array}{c}\text { McCormick et al. (1996) [41], } \\
\text { McKee et al. (1997) [42] }\end{array}$ & Pomponi & 2 & $\mathrm{Y}$ & Y & $Y^{2}$ & Stelletta sp. & R. globostellata & $\mathrm{Y}$ \\
\hline Rao et al. (1997) [19] & Van Soest & 2 & Y & $\mathrm{Y}$ & $\mathrm{Y}^{1}$ & R. globostellata & - & $\mathrm{N}$ \\
\hline $\begin{array}{l}\text { Bourguet-Kondracki et al. } \\
\text { (2000) [43] }\end{array}$ & Lévi & - & Y & $\mathrm{Y}$ & $\mathrm{Y}$ & R. globostellata & - & $\mathrm{N}$ \\
\hline Zampella et al. (2000) [44] & Hooper & - & Y & Y & $\mathrm{Y}^{2}$ & Jaspis sp. & R. globostellata & Y \\
\hline Tabudravu \& Jaspars (2001) [45] & Hooper & - & Y & Y & Y & G. globostellifera & R. globostellata & Y \\
\hline Zhang \& Che (2001) [28] & Chupu & - & Y & $\mathrm{N}$ & $\mathrm{N}$ & G. japonica & Geodia sp.? & $\mathrm{Y}$ \\
\hline Meragelman et al. (2001) [46] & Kelly & - & Y & $\mathrm{Y}$ & $\mathrm{Y}^{2}$ & Jaspis sp. & R. globostellata & $\mathrm{Y}$ \\
\hline Tasdemir et al. (2002) [25] & Harper & - & $\mathrm{Y}$ & $\mathrm{N}$ & $\mathrm{Y}$ & R. globostellata & $\begin{array}{l}\text { Rhabdastrella cf. } \\
\text { globostellata }\end{array}$ & $\mathrm{N}$ \\
\hline $\begin{array}{l}\text { Lv et al. (2004) [47], } \\
\text { Lv et al. (2008) [48] }\end{array}$ & Van Soest & - & Y & Y & $\mathrm{Y}^{1}$ & $R$. aff. distincta & R. globostellata & Y \\
\hline $\begin{array}{l}\text { Tang et al. (2005) [49] } \\
\text { Tang et al. (2006) [50], } \\
\text { Tang et al. (2007) [51] }\end{array}$ & Van Soest? ${ }^{3}$ & - & $\mathrm{Y}$ & $\mathrm{N}$ & $\mathrm{Y}$ & Jaspis sp. & R. globostellata & Y \\
\hline
\end{tabular}


Table 1. Cont.

\begin{tabular}{|c|c|c|c|c|c|c|c|c|}
\hline Ref. & Identifier & $\begin{array}{l}\text { Description of Voucher } \\
\text { 1. Picture } \\
\text { 2. Color } \\
\text { 3. Spicules } \\
\text { 4. Barcodes }\end{array}$ & $\begin{array}{l}\text { Voucher } \\
(\mathrm{Y} / \mathrm{N})\end{array}$ & $\begin{array}{l}\text { Voucher in } \\
\text { Museum } \\
\text { (Y/N/-) }\end{array}$ & $\begin{array}{c}\text { Voucher } \\
\text { Accessed } \\
(\mathrm{Y} / \mathrm{N} /-)\end{array}$ & $\begin{array}{c}\text { Source } \\
\text { Original ID }\end{array}$ & $\begin{array}{c}\text { Source } \\
\text { Revised ID }\end{array}$ & $\begin{array}{c}\text { Misidentification } \\
\text { (Y/N/?) }\end{array}$ \\
\hline Clement et al. (2006) [52] & Kelly & 1 & Y & $\mathrm{Y}^{1}$ & $\mathrm{Y}^{2}$ & R. globostellata & - & $\mathrm{N}$ \\
\hline Fouad et al. (2006) [33] & Van Soest & 3 & $\mathrm{Y}$ & $\mathrm{Y}$ & $\mathrm{Y}$ & R. globostellata & - & $\mathrm{N}$ \\
\hline Agrawal (2007) [53] & - & - & $\mathrm{N}$ & - & - & R. globostellata & - & - \\
\hline Lin et al. (2007) [30] & JH. Li & - & $\mathrm{Y}$ & $\mathrm{N}$ & $\mathrm{N}$ & S. tenuis & R. globostellata & $\mathrm{Y}$ \\
\hline Hirashima et al. (2010) [55] & Van Soest & - & $\mathrm{Y}$ & $\mathrm{Y}$ & $\mathrm{Y}$ & R. globostellata & - & $\mathrm{N}$ \\
\hline $\begin{array}{l}\text { Li et al. (2010) [56] } \\
\text { Li et al. (2012) [57] }\end{array}$ & de Voogd & 1 & $\mathrm{Y}$ & Y & $\mathrm{Y}$ & R. globostellata & - & $\mathrm{N}$ \\
\hline Tanaka et al. (2011) [34] & Fromont & 2,3 & Y & $\mathrm{Y}$ & $\mathrm{Y}$ & R. cf. globostellata & R. globostellata & $\mathrm{N}$ \\
\hline Tang et al. (2012) [31] & - & - & $\mathrm{Y}$ & $\mathrm{N}$ & $\mathrm{N}$ & J. stellifera & Rhabdastrella sp. & $\mathrm{Y}$ \\
\hline $\begin{array}{l}\text { Jin et al. (2014) [32], } \\
\text { Xu et al. (2016) [59], } \\
\text { Xu et al. (2018) [60] }\end{array}$ & Tang & - & Y & $\mathrm{N}$ & $\mathrm{N}$ & J. stellifera & Rhabdastrella sp. & Y \\
\hline Li et al. (2015) [61] & JH. Li & - & Y & $\mathrm{N}$ & $\mathrm{Y}$ & S. tenuis & R. globostellata & $\mathrm{Y}$ \\
\hline $\begin{array}{l}\text { Kiem et al. (2018) [62], } \\
\text { Dung et al. (2018a) [63], } \\
\text { Dung et al. (2018b) [64] }\end{array}$ & Thun & 1 & Y & $\mathrm{N}$ & $\mathrm{Y}$ & R. providentiae & R. globostellata & Y \\
\hline $\begin{array}{l}\text { Kolesnikova et al. (2019) [35] } \\
\text { Kolesnikova et al. (2021) [65] }\end{array}$ & Grebnev & $1,2,3$ & Y & $\mathrm{N}$ & $\mathrm{Y}$ & Stelletta sp. & R. globostellata & Y \\
\hline Lai et al. (2021) [27] & HH. Li & $1^{4}$ & $Y^{4}$ & - & - & Rhabdastrella sp. & - & $\mathrm{N}$ \\
\hline Trang et al. (2022) [66] & - & 4 & $\mathrm{Y}$ & $\mathrm{N}$ & $\mathrm{Y}$ & R. globostellata & - & $\mathrm{N}$ \\
\hline
\end{tabular}

${ }^{1}$ Museum voucher not specified in the paper. ${ }^{2}$ Specimen accessed second-hand through the notes, pictures and/or observations of another taxonomist. ${ }^{3}$ Although R. van Soest is cited as the identifier, there is no voucher and no record of this specimen in the sponge collections in Amsterdam, so this information is considered doubtful (R. van Soest, pers. comm.). ${ }^{4}$ Voucher \#2017-1221-SP is mentioned by Lai et al. [27], but after examination we concluded this voucher was a very different sponge than the one studied. A mistake during collection of the voucher (K-H Lai, pers. comm.) leads to no voucher for this study. The $18 \mathrm{~S}$ sequence of the original material was unfortunately lost (K-H Lai, pers. comm.). However, the original voucher was photographed before being extracted (Figure 3D): it looks like R. globostellata, but we cannot be sure since there is no voucher. We prefer to keep it identified as Rhabdastrella sp. 

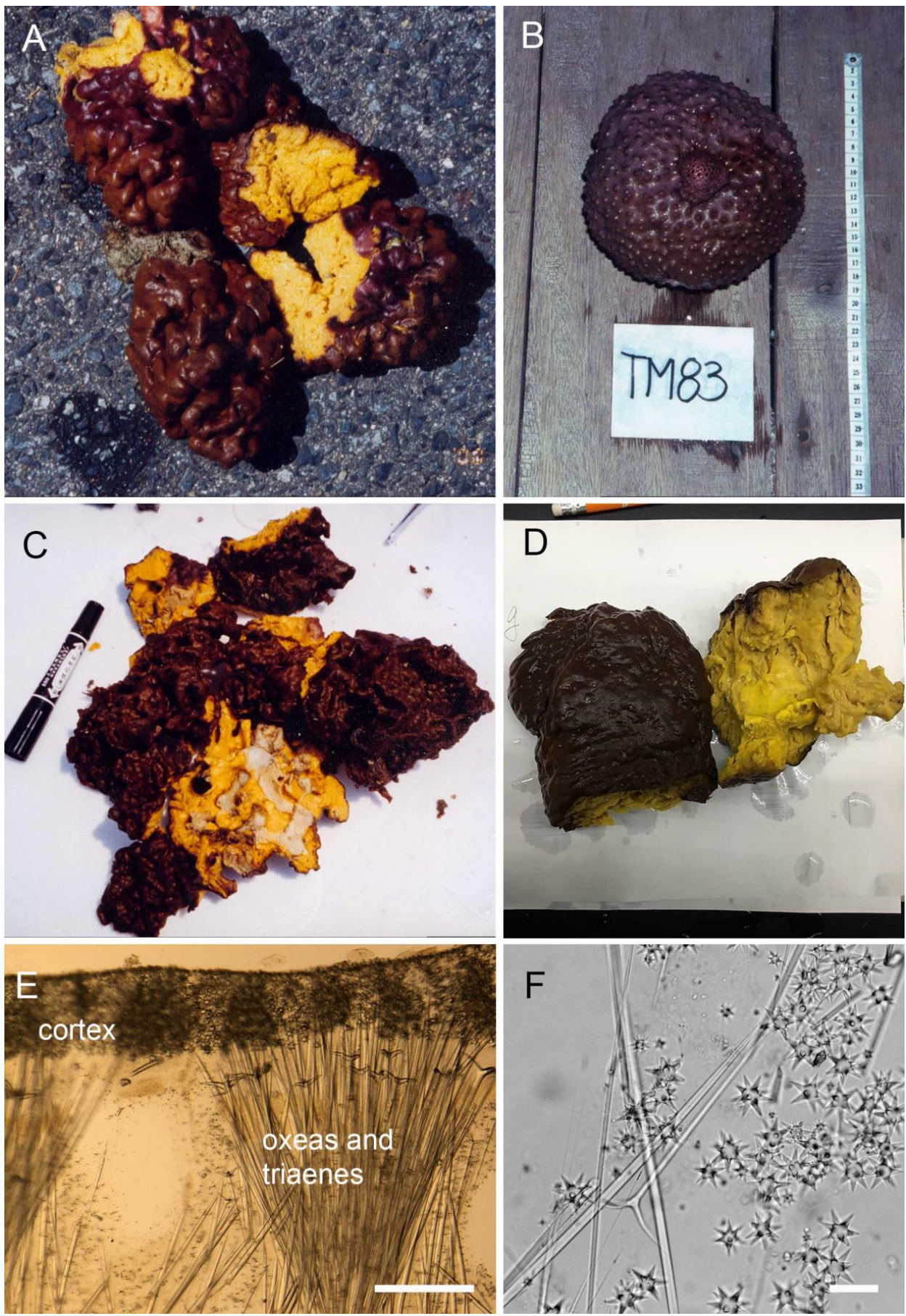

Figure 3. Pictures of specimens used in natural product studies on isomalabaricane triterpenes. (A) Rhabdastrella globostellata (original ID in article), Amami-oshima, Japan, voucher ZMAPOR 16401, Hirashima et al. [55] (Picture: T. Iwagawa). (B) R. globostellata (original ID in article), South Sulawesi, Indonesia, voucher ZMAPOR 17166, Fouad et al. [33] (Picture: R. A. Edrada). (C) Rhabdastrella aff. distincta (original ID in article) $=R$. globostellata (revised ID from this study), Hainan Island, China, voucher ZMAPOR 2717, Lv et al. [47] (Picture: J. Hiort). (D) Rhabastrella sp. before extraction, Lai et al. [27] (Picture: B.-R. Peng). (E) R. cf. globostellata, thick section of cortex showing a dense layer of star-shaped spicules at the surface (oxyspherasters) supported by larger spicules (oxeas and triaenes), voucher PDZ $198-1-10$, Mindanao, Philippines, Tasdemir et al. [25]; scale: $400 \mu \mathrm{m}$. (F) Spicule preparation of Stelletta tenuis (original ID in article) $=$ R. globostellata (revised ID from this study), Hainan Island, China, voucher HN1120-5, Li et al. [61]. Note the characteristic star-shaped spicules (oxyspherasters) of the genus Rhabdastrella and one large triaene; scale: $70 \mu \mathrm{m}$. 
The spicules of all vouchers received were examined and measured, and compared with holotypes (Rhabdastrella globostellata, Rhabdastrella providentiae, Rhabdastrella distincta, Stelletta tenuis), comparative material and taxonomy literature. Out of the 21 vouchers re-examined, 11 (52.4\%) were misidentified. Specimens identified as Jaspis sp., Jaspis stellifera, Stelletta sp., Stelletta tenuis, Geodia globostellifera were all R. globostellata. On the other hand, R. globostellata ZMAPOR 15784a from Sulawesi (Indonesia) was re-identified as Rhabdastrella sp.; it is not $R$. globostellata but a currently undescribed species. The remaining nine vouchers were all confirmed to be $R$. globostellata. Rhabdastrella sp. from Taiwan (Figure 3D) is probably R. globostellata, based on its external morphology, but we cannot be entirely sure since there is no voucher. Since $S$. tenuis HN1120-5 [61] was re-identified as R. globostellata (Figure $3 \mathrm{~F}$ ) and since all S. tenuis identifications stem from the same taxonomist (Table S1), and were published with similar co-authors [29,30,61], one can reasonably consider the other $S$. tenuis records to be misidentifications of $R$. globostellata. Seemingly, most J. stellifera and Jaspis sp. identifications stem from the same authors [31,32,49] who misidentified Jaspis sp. voucher HSC-39 [49-51], which we re-identified as R. globostellata. Therefore, we can confidently conclude that all these Jaspis specimens are R. globostellata as well. Further evidence comes from the distribution of these species. So far, J. stellifera has been formally reported only from South Australia and Tasmania [26] suggesting that it is a temperate species. Therefore, the distributions of $R$. globostellata, a tropical/subtropical species, and J. stellifera do not overlap, which further suggests that all records of J. stellifera in the South China Sea are misidentifications. Following similar reasoning, we consider that NP studies without vouchers using the name Jaspis sp. or J. stellifera, from localities where it has never been observed but where $R$. globostellata is common, are all misidentifications of $R$. globostellata $[9,36,38]$. Despite not being able to revise the G. japonica voucher (presumably lost) from shallow waters of Hainan Island, we are confident that this is a misidentification as well since G. japonica is a temperate deep-sea species only formally recorded from Japan, Korea and Alaska [67-70]. We assume the original material could still have been a Geodia since this genus has very characteristic ball-shaped spicules (sterrasters in Figure 2) that would be difficult to misinterpret for any sponge taxonomist. We are left with the Stelletta sp. from Somalia [37] with no voucher. However, the Somalian coast is in the distribution range of $R$. globostellata, and the authors note the external (brown) and internal (yellow) colors which match with those of $R$. globostellata (Figure 3). It is, therefore, reasonable to think that this is also a misidentification, although we cannot be fully sure without a voucher. Overall, 29 (65.9\%) articles out of the 44 publications were published with a wrong species name. According to our revised identifications, ITTs were isolated only from two species of Rhabdastrella (R. globostellata and Rhabdastrella sp. Indonesia) and one putative species of Geodia (Geodia sp. from the South China Sea). All ITT reports from Stelletta or Jaspis were misidentifications. Following this revision, Table 2 compiles the current chemical diversity of species with ITTs. 
Table 2. Chemical diversity of Rhabdastrella and Geodia species with isomalabaricane triterpenes. Classification of isomalabaricane triterpenes follows [11]. For references to these compounds, see Table S1.

\begin{tabular}{cc}
\hline Species & Compounds \\
\hline
\end{tabular}

Isomalabaricane triterpene groups (ITTs)

\begin{tabular}{|c|c|}
\hline & $\begin{array}{c}\text { Stellettins }^{1} \\
\text { Stellettins A-R, W }{ }^{2} \\
(-)-\text { Stelettin E } \\
\text { Rhabdastrellic Acid-A (=E isomer of stellettin G) } \\
\text { 22,23-dihydrostellettins B, D } \\
\text { Rhabdastrellins A-F } \\
\text { Jaspiferins C-H }\end{array}$ \\
\hline & $\begin{array}{c}\text { Stelliferins } \\
\text { Stelliferins A-N } \\
\text { 29-hydroxystelliferin A, D, E } \\
\text { 3-Epi-29-hydroxystelliferin A, E } \\
\text { 3-Epi-29-acetoxystelliferin E } \\
\text { Stelliferin A, D, ribosides } \\
\text { Geoditins A-B (23E) } \\
\text { Isogeoditins A-B (23Z) } \\
\text { 13- }(\text { E)-isogeoditin A }\end{array}$ \\
\hline $\begin{array}{l}\text { Rhabdastrella } \\
\text { globostellata }\end{array}$ & $\begin{array}{c}\text { Globostellatic acids } \\
\text { Globostellatic acids A-M } \\
\text { Globostelletin A-I } \\
\text { 13,17-Globostellatic acid X methyl esters } \\
\text { Globostellatic acid F methyl ester } \\
\text { Globostellatic acid B methyl ester }\end{array}$ \\
\hline & $\begin{array}{c}\text { ITT derivatives } \\
\text { Aurorals 1-4 (derivatives of globostellatic acids) } \\
\text { Cyclobutastellettolides A and B } \\
\text { Globostelletins A-I (derivatives of stellettin E?) } \\
\text { Globostelletins J-R (cyclopentane side chain) } \\
\text { Jaspiferals A-G (derivatives of globostellatic acids) } \\
\text { 3-O-Acetyl-jaspiferals B/D/E methyl ester } \\
\text { Jaspiferins A-B, I-J (derivatives of stelliferins?) } \\
\text { Jaspiferoic acids A-B dimethyl esters (derivatives of } \\
\text { globostellatic acids) } \\
\text { Jaspolides A-B } \\
\text { Jaspolides C-F (derivatives) } \\
\text { Jaspolides G-H (dimeric) } \\
\text { Rhabdastrellins G-K } \\
\text { Rhabdaprovidines A-C (biochemical degradation of ITTs?) } \\
\text { Rhabdaprovidines D-G } \\
\text { Stellettins S-V (nor-terpenoids) } \\
\text { Rhabdaglostelones A-C (tetra/pentacyclic) }\end{array}$ \\
\hline
\end{tabular}


Table 2. Cont.

\begin{tabular}{|c|c|}
\hline Species & Compounds \\
\hline & $\begin{array}{l}\text { Other compounds } \\
\text { Monocyclic triterpene glycoside: Rhabdastoside A, } \\
\text { Sterols, [71] } \\
\text { Fatty acids, [72] } \\
\text { gibepyrone F, } \\
\text { gibepyrone C, } \\
\text { p-hydroxy benzaldehyde, } \\
\text { 3-Indole-3-aldehyde, } \\
\text { thymine, } \\
\text { p-hydroxy benzaldehyde, } \\
\text { 3-indole-3-aldehyde } \\
\text { cyclo (S-leucyl-S-prolyl), } \\
\text { cyclo (L-Pro-L-Phe) (from bacterial symbiont [73]), } \\
\text { cyclo (L-Pro-L-Leu) (from bacterial symbiont [73]), } \\
\text { cyclo (D-Pro-D-Val) (from bacterial symbiont [74]) }\end{array}$ \\
\hline Rhabdastrella sp. ${ }^{3}$ Taiwan & Rhabdastins H-I \\
\hline $\begin{array}{c}\text { Rhabdastrella sp. }{ }^{4} \\
\text { Indonesia }\end{array}$ & $\begin{array}{l}\text { Globostellatic acid X methyl esters, } \\
\text { Globostellatic acid F methyl ester, } \\
\text { 13-(E)-Globostellatic acid B methyl ester, } \\
\text { Acetyljaspiferal E }\end{array}$ \\
\hline $\begin{array}{l}\text { Geodia sp. } \\
\text { South China Sea }\end{array}$ & $\begin{array}{c}\text { Geoditins A-B }(23 E) \\
\text { Stellettins A-B }\end{array}$ \\
\hline \multicolumn{2}{|c|}{$\begin{array}{l}\text { 1 Stellettins named after the sponge genus Stelletta are spelled with two 't's [29]. However, they are regularly } \\
\text { misspelled in the literature as 'stelletins'. More confusing is that globostelletins were originally spelled with one } \\
\text { ' } t \text { ' [56]. }{ }^{2} \text { Stellettin N from Li et al. [61] is here renamed stellettin W, as stellettin N was already given to another } \\
\text { compound by Xue et al. [58]. }{ }^{3} \text { This is probably } R \text {. globostellata according to the external morphology (Figure 3D) } \\
\text { but we cannot be sure since there is no voucher. }{ }^{4} \text { This is potentially a new species of Rhabdastrella awaiting } \\
\text { formal description. }\end{array}$} \\
\hline
\end{tabular}

\subsection{NP Journal Taxonomy/Voucher Guidelines}

We reviewed the taxonomy/voucher guidelines for $11 \mathrm{NP}$ journals that currently publish most sponge articles. Seven of these have no guidelines or requirements for vouchers or taxonomic identifications: Tetrahedron Letters, Tetrahedron, Bioorganic \& Medicinal Chemistry Letters, Natural Product Communications, Bioorganic \& Medicinal Chemistry, Natural Product Research and Steroids. Only four journals mention voucher guidelines: Marine Drugs, Journal of Natural Products, Phytochemistry Letters and Molecules. Guidelines in Marine Drugs and Molecules (both MDPI publications) are identical and only refer to "research involving plants", with no mention of marine organisms. Although MDPI guidelines request GPS coordinates of the locality and that "voucher specimens must be deposited in an accessible herbarium or museum", some sponge NP articles from these journals do not follow these guidelines [75-77]. Phytochemistry Letters has clear guidelines in terms of deposition of the plant vouchers in an herbarium, checking the validity of the species name and including an illustration if the species is poorly known. Although they do not clearly transfer these requirements to marine organisms, authors must consider that it applies to sponges as well. However, recent sponge NP studies in Phytochemistry Letters have not had their specimens identified by a sponge taxonomist and more importantly have not deposited their vouchers in a museum $[62,78,79]$. Journal of Natural Products has detailed guidelines to report the species identification; if the specimen is not identified to the species level, a description is required; the identifier should be an expert in the organisms studied, but they do not require the publication of the name of the identifier; the voucher should be deposited in a "herbarium" (but do not mention museums for animal material); the GPS coordinates are only recommended. Some sponge studies in Journal of Natural Products are still depositing vouchers in university or lab collections $[80,81]$. 


\section{Discussion}

\subsection{Rhabdastrella globostellata Is a Variable Species}

By collecting vouchers and voucher pictures, we noticed some shape variations in R. globostellata. This species is usually a massive subglobular species which can be cupshaped in large specimens (Figure 3B), but a morphotype with a convoluted surface (brainlike) seemed also quite common (Figure 3A) in the South and East China Sea: ZMAPOR 16401 from Hirashima et al. [55], ZMAPOR 12451 from Rao et al. [19], PIBOC O38-301 from Kolesnikova et al. [35,65], HM06-2016.1 from Kiem et al. [62] and NCCT-B139 from Trang et al. [66]. Morphology and measurements of the spicules from both morphotypes did not reveal any consistent differences. We wonder whether the brain-like morphotype could represent a separate cryptic lineage, but molecular markers are required to further test this.

Spicule variations of $R$. globostellata were observed for other specimens. We confirm that triaene spicules (Figure 1) were overall vestigial or absent in vouchers from Western Pacific subtropical populations, a variation mentioned already [26]. Since Jaspis is a genus without triaenes (Figure 1), this loss of triaenes is the main reason $R$. globostelletta has often been mistaken for a Jaspis in these regions. This is how R. globostelletta started to be wrongly identified as J. stellifera in the Great Barrier Reef [82]. The loss of triaenes is actually a common feature of several other Rhabdastrella species (e.g., R. cribriporosa, R. distincta).

\subsection{ITTs Are Chemotaxonomy Markers}

Our results also shed light on the chemotaxonomy of Rhabdastrella. Van Soest \& Braekman [4] had suggested ITTs were markers of the Ancorinidae family in which we find Stelletta, Jaspis and Rhabdastrella. Later, acknowledging some misidentifications, Tasdemir et al. [25] claimed that "isomalabaricanes are chemotaxonomic markers for R. globostellata". However, our results invalidate this claim and confirms the presence of ITTs in at least two Rhabdastrella species-R. globostellata and Rhabdastrella sp. Indonesia-as well as one Geodia sp. from the South China Sea. A shared chemical marker between Rhabdastrella and Geodia is not unexpected as they have shown to be phylogenetically close [24]. More Geodia species will need to be tested for the presence of ITTs to confirm this association.

Table 2 compiles the resulting chemical diversity of species with ITTs. $R$. globostellata is by far the richest species in terms of ITTs diversity with 160 different ITTs in this single species. Future work will now need to investigate if different chemical lineages could be revealed in the Indo-Pacific region, which could eventually be correlated with cryptic genetic lineages. The true producer of these ITTs, sponge and/or microbial symbiont is presently unknown. The microbiome of $R$. globostellata, a High Microbial Abundance (HMA) sponge, was studied with $16 \mathrm{~S}$ amplicon sequencing on specimens from Guam [83,84] and Vietnam [85]. In the specimens from Guam, 23 microbial phyla were detected in the microbiome, the most abundant ones being Acidobacteria, Chloroflexi SAR202, Cyanobacteria, Gemmatimonadetes and Alphaproteobacteria; the predominant bacterium was a Cyanobacteria highly similar to Candidatus Synechococcus spongiarum [84]. Cultured bacterial symbionts have been shown to produce small molecules, including diketopiperazines (Table 2) $[73,74]$, but no ITTs so far. The sharing of ITTs between R. globostellata, Rhabdastrella sp. Indonesia and Geodia sp. therefore suggests either phylogenetic closeness or the sharing of a highly specific symbiont. Our results also have repercussions for other NP articles reporting sterol and fatty acid composition in J. stellifera $[71,72,86]$. For the same reasons given in the present study and previous ones [26,87], we are confident that these studies are also on misidentified R. globostellata.

\subsection{Sponge Misidentifications Have Multiple Reasons}

Sponges are admittedly a challenging group to work with in taxonomy. Thanks to an increasing amount of molecular data, the traditional classifications have seen some drastic changes these last years, in the four classes of sponges: Demospongiae [88,89], Hexactinellida [90], Calcarea [91,92] and Homoscleromorpha [93]. These changes, added 
to the subtleties and caveats of spicule terminology, the dense taxonomy literature (not free of identification errors) make sponge taxonomy a challenging field for a non-specialist. However, reproducibility and reusability of NP results do rely on rigorous taxonomic identification of the specimens investigated, so that for example promising bioactive compounds can be re-isolated from the same organisms. Our results show that a very high number of articles $(29,65.9 \%)$ were published with a wrong genus/species name (Table 1 ). However, to identify the specimens, most of these papers (22) collaborated with a demosponge taxonomist (i.e., a taxonomist with a track record of publications in that field) while 14 articles collaborated with a more general taxonomist (Table 1). Demosponge taxonomists were mistaken 11 times (out of 22), which in itself highlights the challenge of sponge identification, even for experts. None of the general taxonomists got the species name right. Reasons why experts make mistakes is species morphological variability (cf. Section 3.1) and poor description of species from the 19th century where the type material has never been revised, which was the case for Jaspis stellifera and Stelletta tenuis. Cascading errors in sponge NP publications are often the result of an original error from an identifier, repeated along a series of articles usually from the same lab or authors (Table S1). For instance, from the 1970s to the 1990s, all the Rhabdastrella globostellata that were collected at Heron Island, Queensland (Eastern Australia) were misidentified as J. stellifera following the demosponge taxonomist Patricia R. Bergquist [82]. This explains why Australian taxonomists continued using J. stellifera or Jaspis sp. for R. globostellata from Japan. Kennedy [26] revealed the mistake, relayed by Tasdemir et al. [25] to the NP community but the name $J$. stellifera was inappropriately used again more recently on material from the South China Sea $[31,32,59,60]$. Another misidentification name for R. globostellata is $S$. tenuis $[29,30,61]$, also appearing in sponge microbiology publications $[73,94,95]$. We have examined the $S$. tenuis voucher HN1120-5 [61] (Figure 3F). Based on its spicules and comparison with the holotypes of $S$. tenuis and R. globostellata, it is without any doubt R. globostellata. Actually, $S$. tenuis has never been formally reported since its original description in Java in 1897 [96], therefore all publications mentioning $S$. tenuis without a clear description of the specimen are suspicious and most likely all refer to R. globostellata.

\subsection{The Accessibility of Vouchers Is Crucial}

The fact that even sponge taxonomists misidentified some specimens (Table 1) highlights the crucial importance of depositing a voucher for every published study, so that identifications can be revised. Most NP studies after the 1990s do have a voucher with a collection number. However, a voucher is not sufficient, as we found that access to vouchers is also crucial. Indeed, as a byproduct of the study, one should consider vouchers as data in itself, which should therefore ideally follow the FAIR principles (Findable, Accessible, Interoperable, Reusable) [8]. The accessibility of vouchers deposited at universities, institutions or lab collections can be increasingly difficult with time. Vouchers stored in labs, university departments or even institutes do not ensure that they will be preserved and easily accessible to the scientific community after some years. Many of these collections risk being lost with time, movement/retirement of researchers or restructuration of labs. In the case of ITT sponge vouchers, many voucher fragments were fortunately sent for identification to taxonomists R. van Soest and N. de Voogd (Naturalis Museum, The Netherlands), so that we were able to access them easily through the museum collections. Sponge vouchers should ideally be stored in national or city museums, where long-term curation and accessibility to international scientists will be guaranteed, and will be an easy process. Only $14(53.8 \%)$ out of the 26 vouchers were stored in a museum (Table 1$)$. The other 12 vouchers coming from 2002-2022 publications were stored in university or lab collections and were obtained by contacting the authors. We were able to access all vouchers in museum collections, but only eight of the 12 vouchers stored in university/institute collections (Table 1) and that is sometimes only possible with substantial detective work to locate the vouchers or the authors. We envision that with time, these 12 vouchers will become less accessible, as the authors move on and as labs are restructured or dismantled. Of course, 
this does not concern large well-curated NP collections/platforms which ensure from the start proper voucher handling/curation and potential long-term storage (e.g., NatureBank, https: / / www.griffith.edu.au/institute-drug-discovery/unique-resources/naturebank (accessed 1 March 2022); the Harbor Branch Oceanographic Institute Marine Biotechnology Reference Collection (HBOI MBRC) http:/ / hboi-marine-biomedical-and-biotechnologyreference-collection.fau.edu/app/data-portal (accessed 1 March 2022); the National Cancer Institute (NCI) Natural Products Repository https:/ / dtp.cancer.gov / organization/npb/ introduction.htm (accessed 1 March 2022)). However, to our knowledge, none of these large collections take in vouchers from other studies.

By losing a voucher, one loses proof of the source organism, which could make the study non-reproducible and the compound not findable again. For example, since the Geodia from Zhang \& Che [28] was most probably misidentified, the loss of the voucher means we do not know which Geodia species produces ITTs and if it is a Geodia indeed. Apart from hampering reproducibility, misleading future NP or chemotaxonomy studies, and just generally minimizing the scientific impact of the study, one should not forget as well the many repercussions of these misidentifications. For example, they partly invalidate the many chemistry review articles, e.g., on compounds from Jaspis [97] or Stelletta [98] which repeatedly propagate the same errors. This may for example lead to false scientific questions such as trying to reconcile the shared appearance of ITTs in Jaspis, Stelletta and Rhabdastrella species. Overall, these errors will become a source of recurrent confusion until corrected and revised. Additionally, with scientific advancements and access to new technologies, techniques such as genome mining to unravel the biosynthetic pathways of natural products are becoming common. Misidentifications will waste money, time and hamper such possibilities because scientific efforts could be wasted on the wrong species. In a time when 'drug repurposing' is a hot area for natural products, knowing which organism actually produces the compound is vital to establish feasible methods of production. The problem of sponge misidentification has been raised previously in the field of NPs [4,5]. The present study is, to our knowledge, only the second [7] to revise a set of sponge NP vouchers to solve putative inconsistencies, and therefore assess the problem of misidentification in the field of sponge NPs. This study is however the first to highlight the problem of voucher accessibility in the field of sponge NPs.

\subsection{Recommended Protocol for Sponge NP Studies}

To reduce future widespread misidentification issues in the field of sponge NP studies, we would like to take the opportunity of this study to (i) recommend a common (ideal) protocol for reporting of sponges for NP studies and (ii) advocate for stricter guidelines for NP journals publishing these works, as well as for higher expectations from peer reviewers, thereby improving the general standards of the field. With more and more sponge NP studies integrating sponge genomic data, it goes without saying that vouchers are also to be kept and deposited for sequenced specimens. We are aware of the difficulties of fieldwork which sometimes limit what can be done but sponge and sponge-associated microbe NP studies should try to follow as much as possible this protocol to maximize the scientific impact and reproducibility of their study.

1. Upon collection, take pictures of the whole specimen (external and internal appearance). A picture of the specimen is priceless for a sponge taxonomist and can already give a lot of information about the species identity (shape, external/internal color). Usually, the voucher is a small subsample so one loses substantial information about the external morphology if a taxonomist only examines the voucher.

2. Prepare the voucher from the start, upon collection of the specimen in the field. Just after collection, cut a small piece $(1 \mathrm{~cm} \times 1 \mathrm{~cm})$ including the surface of the sponge. Place the piece in 10 times its volume of EtOH 96\% to preserve the DNA and the morphology. Change the EtOH at least twice, after $\sim 1 \mathrm{~h}$ and after $\sim 6 \mathrm{~h}$. Of course, a larger voucher is perfectly ok, but then increase the amount of EtOH $96 \%$ accordingly to properly preserve the DNA (that being said, DNA is usually preserved better in 
a small piece). With this mode of preservation, the voucher could be used in the future for morphology and molecular work (e.g., barcoding, population genetics, genomics, etc.) and it is easily stored at room temperature.

3. A voucher should have the following metadata recorded and reported in the publication: date of collection, collector, locality name, GPS coordinates, depth and habitat (e.g., coral reef, seagrass bed, mangrove, rocky bottom) of the locality where the specimen was collected. These descriptors will be useful for several metadata analyses (e.g., [99]) as well as for the taxonomist.

4. Collaborate with a sponge taxonomist for the identification. Indicate in the publication the name of the taxonomist identifier. Sponge experts can be found on the World Porifera Database (WPD, http: / / www.marinespecies.org/porifera, accessed 1 March 2022): WPD editors are listed on the home webpage, and additional experts are listed in the "Who is who in sponge science" list [100].

5. Check the validity and spelling of the species name on the WPD before publishing. All species and their taxonomy are recorded and updated in the WPD, part of the World Register of Marine Species (WoRMS).

6. With the help of the sponge taxonomist, include in the publication a short description of specimen with (i) external and internal color (the best is a picture), (ii) overall shape, and if possible, (iii) spicule repertoire with spicule measurements. It will significantly help other taxonomists to trust or not the identification. These descriptions can be in the Materials section (e.g., [33,101]) or in the Supplementary Information (e.g., [35]). This description should be mandatory if the specimen is identified to the genus level only. Additionally, including a molecular barcode of the specimen in the publication (and deposited in Genbank) can be very useful: $28 \mathrm{~S}$ and COI (cytochrome c oxidase 1) are the two most widely used barcodes to help with sponge identification.

7. Deposit the sponge voucher in a recognized national or city museum with a unique museum number to be included in the publication. The sponge taxonomist collaborator may help you with this last step.

To conclude, species misidentification may always exist in sponge NP studies, but one of the best solutions to promote reproducibility and corrections of errors is for NP journals to require for publication no less than (i) a description of the sponge (picture included) and (ii) that vouchers be deposited in a recognized museum.

\section{Materials and Methods}

\subsection{Abbreviations}

NHM, Natural History Museum, London, UK; UPSTZY, type collection of the Zoological Museum of Uppsala, Uppsala, Sweden; ZMAPOR, Amsterdam Porifera collection, now stored at Naturalis, Leiden, The Netherlands; ZMB, Museum für Naturkunde, Berlin, Germany.

\subsection{Comparative Material and Vouchers}

After compiling all NP articles reporting ITTs (until January 2022), a list was obtained of eight sponge species from four genera (Rhabdastrella globostellata (Carter, 1883), Rhabdastrella providentiae (Dendy, 1916), Rhabdastrella aff. distincta (Thiele, 1900), Geodia japonica (Sollas, 1888), Geodia globostellifera Carter, 1880, Stelletta tenuis Lindgren, 1897, Stelletta globostellata Carter, 1883, Jaspis stellifera (Carter, 1879)) and three undetermined species (Stelletta sp., Jaspis sp., Rhabdastrella sp.). Undetermined species were used in different articles so they could actually represent different species. We checked the validity of each of the eight species names in the World Porifera Database (WPD, http: / / www.marinespecies.org/porifera, accessed 1 March 2022), part of the World Register of Marine Species (WoRMS). Species were all valid except for S. globostellata, which is a junior synonym of $R$. globostellata (i.e., the species is correct, but the genus is not correct anymore). To revise the identification of vouchers, comparative material was necessary and ideally one would try to compare with the species holotypes, which are the specimens from the original descriptions. The following holotypes were therefore obtained on loan from 
museums: Rhabdastrella globostellata (NHM 1883.5.3.1, Galle, Sri Lanka, slide), Rhabdastrella providentiae (NHM 1920.12.9.129 and 1920.12.9.74a, Providence Island, Seychelles, slides), Rhabdastrella distincta (ZMB 3190, Ternate, Indonesia, slides) and Stelletta tenuis (UPSTZY 2099, Java, Indonesia, wet specimen and slides). We also relied on the re-descriptions of the holotypes of R. globostellata and J. stellifera [26]. Re-identification of vouchers were done by PC and JG.

Some studies did not have a voucher (essentially articles from the 1980s and 1990s). For the other studies, sponge vouchers and/or pictures of vouchers were obtained by emailing authors or institutes/museums where vouchers were deposited, as described in the articles. We have also in some cases contacted the taxonomist who identified the material (when cited in the article) since they would often keep a spicule preparation or notes of what they identify. It is worthy of note that some NP publications included a more or less short description of the specimen so that it was directly possible to confirm or refute some of the identifications, before examining the voucher.

\subsection{Spicule Preparations}

Spicule preparations of the vouchers were prepared by digesting a piece of sponge $(5 \times 2 \mathrm{~mm})$ in chlorine in a 1.5-2 $\mathrm{mL}$ Eppendorf tube. One voucher received as grinded powder was treated the same way by placing a few $\mathrm{mg}$ of powder in chlorine. When the tissue was entirely dissolved, the remaining spicules were washed successively with $\mathrm{H}_{2} \mathrm{O}, 50 \% \mathrm{EtOH}$ and $100 \% \mathrm{EtOH}$. A drop of the spicule solution on a glass slide was left to dry, on a hot plate. Then the spicules were covered with Eukitt ${ }^{\mathrm{TM}}$ mounting medium (Sigma-Aldrich, St Louis, MO, USA) and a cover slide to make permanent slides. Spicules were examined with a light microscope, measured using an eye-piece micrometer, and documented by taking pictures with a camera connected to the microscope.

\subsection{Voucher Guidelines in NP Journals}

To assess sponge voucher recommendations in NP journals, we focused on journals that currently publish most sponge NP studies. For this, we searched for NP journals that published $>10$ articles with "marine sponge" in their title between January 2010 and April 2021. We retrieved 11 journals, here sorted according to the number of sponge NP articles found: Marine Drugs (175), Journal of Natural Products (117), Tetrahedron Letters (66), Tetrahedron (65), Bioorganic \& Medicinal Chemistry Letters (64), Natural Product Communications (41), Bioorganic \& Medicinal Chemistry (39), Natural Product Research (32), Phytochemistry Letters (19), Molecules (15) and Steroids (12). Author guidelines in these 11 journals was reviewed, with respect to taxonomy and vouchers.

Supplementary Materials: The following supporting information can be downloaded at: https:// www.mdpi.com/article/10.3390/md20030190/s1, Table S1: List of publications (1981-2022) reporting isomalabaricane triterpenes and derivatives from marine sponges.

Author Contributions: Design of study, P.C.; retrieval of vouchers and comparative material, P.C.; NP journal guidelines comparison: J.G.; identification of vouchers and analysis of the data, P.C., J.G. supervision: P.C., C.M.H., S.G.; funding acquisition: S.G.; writing of the manuscript, P.C.; editions of the manuscript: J.G., C.M.H. and S.G. All authors have read and agreed to the published version of the manuscript.

Funding: This work was supported by a network grant Swedish Research Links \#2017-05416 with Sri Lanka from the Swedish Research Council (PI: S.G.).

Institutional Review Board Statement: Not applicable.

Data Availability Statement: All species identifications generated during this study are available in Tables 1 and S1. 
Acknowledgments: The authors gratefully acknowledge the researchers that provided vouchers, pictures/observations of vouchers and/or observations on vouchers: M. K. Harper (Department of Medicinal Chemistry, University of Utah, Salt Lake City, Utah, USA), L. J. Bell (Coral Reef Research Foundation, Palau), M. Kelly (NIWA, New Zealand), M. Jaspars (Marine Biodiscovery Centre, Department of Chemistry, University of Aberdeen, Scotland, UK), M.-L. Bourguet-Kondracki (Biochimie des Interactions Microbiennes, MNHN, Paris, France), J. N. A. Hooper (Queensland Museum, Brisbane, Australia), J. Fromont (Western Australian Museum, Perth, Australia), C. C. Branco (Smithsonian NMNH, USA), R. van Soest and N. de Voogd (Naturalis Biodiversity Center, Leiden, The Netherlands), L. Li (Department of Pharmacy, Ren Ji Hospital, School of Medicine, Shanghai Jiao Tong University, Shanghai, China), W. Lin (State Key Laboratory of Natural and Biomimetic Drugs, Peking University, China), B. Chen and Y.-W. Guo (Shanghai Institute of Materia Medica, Chinese Academy of Sciences, Shanghai, China), S. Kolesnikova and B. Grebnev (G.B. Elyakov Pacific Institute of Bioorganic Chemistry (PIBOC), Vladivostok, Russia), N. X. Nhiem and P. V. Kiem (Department of Structural Research, Institute of Marine Biochemistry, Vietnam Academy of Science and Technology, Hanoi, Vietnam), K.-H. Lai (Taipei Medical University, Taiwan).

Conflicts of Interest: The authors declare no conflict of interest. The funder had no role in the design of the study; in the collection, analyses, or interpretation of data; in the writing of the manuscript, or in the decision to publish the results.

\section{References}

1. Leal, M.C.; Hilario, A.; Munro, M.H.G.; Blunt, J.W.; Calado, R. Natural products discovery needs improved taxonomic and geographic information. Nat. Prod. Rep. 2016, 33, 747-750. [CrossRef] [PubMed]

2. Bennett, B.C.; Balick, M.J. Does the name really matter? The importance of botanical nomenclature and plant taxonomy in biomedical research. J. Ethnopharmacol. 2014, 152, 387-392. [CrossRef] [PubMed]

3. Rivera, D.; Allkin, R.; Obón, C.; Alcaraz, F.; Verpoorte, R.; Heinrich, M. What is in a name? The need for accurate scientific nomenclature for plants. J. Ethnopharmacol. 2014, 152, 393-402. [CrossRef] [PubMed]

4. Van Soest, R.W.M.; Braekman, J.C. Chemosystematics of Porifera: A review. Mem. Qld. Mus. 1999, 44, 569-589.

5. Erpenbeck, D.; van Soest, R.M. Status and Perspective of Sponge Chemosystematics. Mar. Biotechnol. 2007, 9, 2-19. [CrossRef]

6. Leal, M.C.; Puga, J.; Serôdio, J.; Gomes, N.C.M.; Calado, R. Trends in the Discovery of New Marine Natural Products from Invertebrates over the Last Two Decades-Where and What Are We Bioprospecting? PLoS ONE 2012, 7, e30580. [CrossRef]

7. Van Soest, R.W.M.; Braekman, J.C.; Faulkner, D.J.; Hajdu, E.; Harper, M.K.; Vacelet, J. The genus Batzella: A chemosystematic problem. Bull. L'institut R. Sci. Nat. Belg. Série Biol. 1996, 66, 89-101.

8. Wilkinson, M.D.; Dumontier, M.; Aalbersberg, I.J.; Appleton, G.; Axton, M.; Baak, A.; Blomberg, N.; Boiten, J.-W.; da Silva Santos, L.B.; Bourne, P.E.; et al. The FAIR Guiding Principles for scientific data management and stewardship. Sci. Data 2016, 3, 160018. [CrossRef]

9. Ravi, B.N.; Wells, R.J.; Croft, K.D. Malabaricane triterpenes from a Fijian collection of the sponge Jaspis stellifera. J. Org. Chem. 1981, 46, 1998-2001. [CrossRef]

10. Stonik, V.A.; Kolesnikova, S.A. Malabaricane and Isomalabaricane Triterpenoids, Including Their Glycoconjugated Forms. Mar. Drugs 2021, 19, 327. [CrossRef]

11. Ebada, S.S.; Lin, W.; Proksch, P. Bioactive Sesterterpenes and Triterpenes from Marine Sponges: Occurrence and Pharmacological Significance. Mar. Drugs 2010, 8, 313-346. [CrossRef] [PubMed]

12. Tang, S.-A.; Zhou, Q.; Guo, W.-Z.; Qiu, Y.; Wang, R.; Jin, M.; Zhang, W.; Li, K.; Yamori, T.; Dan, S.; et al. In Vitro Antitumor Activity of Stellettin B, a Triterpene from Marine Sponge Jaspis stellifera, on Human Glioblastoma Cancer SF295 Cells. Mar. Drugs 2014, 12, 4200-4213. [CrossRef] [PubMed]

13. Wang, R.; Zhang, Q.; Peng, X.; Zhou, C.; Zhong, Y.; Chen, X.; Qiu, Y.; Jin, M.; Gong, M.; Kong, D. Stellettin B Induces G1 Arrest, Apoptosis and Autophagy in Human Non-small Cell Lung Cancer A549 Cells via Blocking PI3K/Akt/mTOR Pathway. Sci. Rep. 2016, 6, 27071. [CrossRef]

14. Chen, Y.; Zhou, Q.; Zhang, L.; Zhong, Y.; Fan, G.; Zhang, Z.; Wang, R.; Jin, M.; Qiu, Y.; Kong, D. Stellettin B induces apoptosis in human chronic myeloid leukemia cells via targeting PI3K and Stat5. Oncotarget 2017, 8, 28906-28921. [CrossRef] [PubMed]

15. Cheng, S.-Y.; Chen, N.-F.; Lin, P.-Y.; Su, J.-H.; Chen, B.-H.; Kuo, H.-M.; Sung, C.-S.; Sung, P.-J.; Wen, Z.-H.; Chen, W.-F. AntiInvasion and Antiangiogenic Effects of Stellettin B through Inhibition of the Akt/Girdin Signaling Pathway and VEGF in Glioblastoma Cells. Cancers 2019, 11, 220. [CrossRef] [PubMed]

16. Carter, H.J. Contributions to our Knowledge of the Spongida. -Pachytragida. Ann. Mag. Nat. Hist. 1883, 5, 344-369, pls XIV-XV. [CrossRef]

17. De Voogd, N.J.A.B.; Boury-Esnault, N.; Carballo, J.L.; Cárdenas, P.; Díaz, M.-C.; Dohrmann, M.; Downey, R.; Hajdu, E.; Hooper, J.N.A.; Kelly, M.; et al. World Porifera Database. Available online: http:/ /www.marinespecies.org/porifera (accessed on 13 February 2022). 
18. Ryu, G.; Matsunaga, S.; Fusetani, N. Globostellatic Acids A-D, New Cytotoxic Isomalabaricane Triterpenes from the Marine Sponge Stelletta globostellata. J. Nat. Prod. 1996, 59, 512-514. [CrossRef]

19. Rao, Z.; Deng, S.; Wu, H.; Jiang, S. Rhabdastrellic Acid-A, a Novel Triterpenoid from the Marine Sponge Rhabdastrella globostellata. J. Nat. Prod. 1997, 60, 1163-1164. [CrossRef]

20. Van Soest, R.W.M.; Boury-Esnault, N.; Vacelet, J.; Dohrmann, M.; Erpenbeck, D.; De Voogd, N.J.; Santodomingo, N.; Vanhoorne, B.; Kelly, M.; Hooper, J.N.A. Global Diversity of Sponges (Porifera). PLoS ONE 2012, 7, e35105.

21. Jørgensen, C.B. On the spicule-formation of Spongilla lacustris (L.) 1. The dependence of the spicule-formation on the content of dissolved and solid silicic acid of the milieu. Biol. Medd. (Det K. Dan. Vidensk. Selsk.) 1944, 19, 1-45.

22. Maldonado, M.; Carmona, M.C.; Uriz, M.J.; Cruzado, A. Decline in Mesozoic reef-building sponges explained by silicon limitation. Nature 1999, 401, 785-788. [CrossRef]

23. Cárdenas, P.; Rapp, H.T. Disrupted spiculogenesis in deep-water Geodiidae (Porifera, Demospongiae) growing in shallow waters. Invertebr. Biol. 2013, 132, 173-194. [CrossRef]

24. Cárdenas, P.; Xavier, J.R.; Reveillaud, J.; Schander, C.; Rapp, H.T. Molecular phylogeny of the Astrophorida (Porifera, Demospongiae) reveals an unexpected high level of spicule homoplasy. PLoS ONE 2011, 6, e18318. [CrossRef] [PubMed]

25. Tasdemir, D.; Mangalindan, G.C.; Concepcion, G.P.; Verbitski, S.M.; Rabindran, S.; Miranda, M.; Greenstein, M.; Hooper, J.N.A.; Harper, M.K.; Ireland, C.M. Bioactive Isomalabaricane Triterpenes from the Marine Sponge Rhabdastrella globostellata. J. Nat. Prod. 2002, 65, 210-214. [CrossRef]

26. Kennedy, J.A. Resolving the 'Jaspis stellifera' complex. Mem. Qld. Mus. 2000, 45, 453-476.

27. Lai, K.-H.; Huang, Z.-H.; El-Shazly, M.; Peng, B.-R.; Wei, W.-C.; Su, J.-H. Isomalabaricane Triterpenes from the Marine Sponge Rhabdastrella sp. Mar. Drugs 2021, 19, 206. [CrossRef]

28. Zhang, W.-H.; Che, C.-T. Isomalabaricane-Type Nortriterpenoids and Other Constituents of the Marine Sponge Geodia japonica. J. Nat. Prod. 2001, 64, 1489-1492. [CrossRef]

29. Su, J.Y.; Meng, Y.H.; Zeng, L.M.; Fu, X.; Schmitz, F.J. Stellettin A, a New Triterpenoid Pigment from the Marine Sponge Stelletta tenuis. J. Nat. Prod. 1994, 57, 1450-1451. [CrossRef]

30. Lin, H.-w.; Wang, Z.-1.; Wu, J.-h.; Shi, N.; Zhang, H.-j.; Chen, W.-s.; Morris-Natschke, S.L.; Lin, A.-S. Stellettins L and M, Cytotoxic Isomalabaricane-Type Triterpenes, and Sterols from the Marine Sponge Stelletta tenuis. J. Nat. Prod. 2007, 70, 1114-1117. [CrossRef]

31. Tang, S.; Xu, R.; Lin, W.; Duan, H. Jaspiferin A and B: Two New Secondary Metabolites from theSouth China Sea Sponge Jaspis stellifera. Rec. Nat. Prod. 2012, 6, 398-401.

32. Jin, D.-J.; Tang, S.-A.; Xing, G.-S.; Zhao, W.-J.; Zhao, C.; Duan, H.-Q.; Lin, W.-H. Jaspiferins C-F, four new isomalabaricane-type triterpenoids from the South China Sea sponge Jaspis stellifera. J. Asian Nat. Prod. Res. 2014, 16, 427-433. [CrossRef] [PubMed]

33. Fouad, M.; Edrada, R.A.; Ebel, R.; Wray, V.; Muller, W.E.G.; Lin, W.H.; Proksch, P. Cytotoxic Isomalabaricane Triterpenes from the Marine Sponge Rhabdastrella globostellata. J. Nat. Prod. 2006, 69, 211-218. [CrossRef] [PubMed]

34. Tanaka, N.; Momose, R.; Shibazaki, A.; Gonoi, T.; Fromont, J.; Kobayashi, J.I. Stelliferins J-N, isomalabaricane-type triterpenoids from Okinawan marine sponge Rhabdastrella cf. globostellata. Tetrahedron 2011, 67, 6689-6696. [CrossRef]

35. Kolesnikova, S.A.; Lyakhova, E.G.; Kalinovsky, A.I.; Berdyshev, D.V.; Pislyagin, E.A.; Popov, R.S.; Grebnev, B.B.; Makarieva, T.N.; Minh, C.V.; Stonik, V.A. Cyclobutastellettolides A and B, C19 Norterpenoids from a Stelletta sp. Marine Sponge. J. Nat. Prod. 2019, 82, 3196-3200. [CrossRef]

36. Ravi, B.N.; Wells, R.J. Malabaricane triterpenes from a Great Barrier Reef collection of the sponge Jaspis stellifera. Aust. J. Chem. 1982, 35, 39-50. [CrossRef]

37. McCabe, T.; Clardy, J.; Minale, L.; Pizza, C.; Zollo, F.; Riccio, R. A triterpenoid pigment with the isomalabaricane skeleton from the marine sponge Stelletta sp. Tetrahedron Lett. 1982, 23, 3307-3310. [CrossRef]

38. Tsuda, M.; Ishibashi, M.; Agemi, K.; Sasaki, T.; Kobayashi, J.i. Stelliferins A-F, new antineoplastic isomalabaricane triterpenes from the Okinawan marine sponge Jaspis stellifera. Tetrahedron 1991, 47, 2181-2194. [CrossRef]

39. Oku, N.; Matsunaga, S.; Wada, S.-i.; Watabe, S.; Fusetani, N. New Isomalabaricane Triterpenes from the Marine Sponge Stelletta globostellata That Induce Morphological Changes in Rat Fibroblasts. J. Nat. Prod. 2000, 63, 205-209. [CrossRef]

40. Kobayashi, J.i.; Yuasa, K.; Kobayashi, T.; Sasaki, T.; Tsuda, M. Jaspiferals A G, new cytotoxic isomalabaricane-type nortriterpenoids from Okinawan marine sponge Jaspis stellifera. Tetrahedron 1996, 52, 5745-5750. [CrossRef]

41. McCormick, J.L.; McKee, T.C.; Cardellina, J.H.; Leid, M.; Boyd, M.R. Cytotoxic Triterpenes from a Marine Sponge, Stelletta sp. J. Nat. Prod. 1996, 59, 1047-1050. [CrossRef]

42. McKee, T.C.; Bokesch, H.R.; McCormick, J.L.; Rashid, M.A.; Spielvogel, D.; Gustafson, K.R.; Alavanja, M.M.; Cardellina, J.H.; Boyd, M.R. Isolation and Characterization of New Anti-HIV and Cytotoxic Leads from Plants, Marine, and Microbial Organisms. J. Nat. Prod. 1997, 60, 431-438. [CrossRef] [PubMed]

43. Bourguet-Kondracki, M.L.; Longeon, A.; Debitus, C.; Guyot, M. New cytotoxic isomalabaricane-type sesterterpenes from the New Caledonian marine sponge Rhabdastrella globostellata. Tetrahedron Lett. 2000, 41, 3087-3090. [CrossRef]

44. Zampella, A.; D'Auria, M.V.; Debitus, C.; Menou, J.-L. New Isomalabaricane Derivatives from a New Species of Jaspis Sponge Collected at the Vanuatu Islands. J. Nat. Prod. 2000, 63, 943-946. [CrossRef] [PubMed]

45. Tabudravu, J.N.; Jaspars, M. Stelliferin Riboside, a Triterpene Monosaccharide Isolated from the Fijian Sponge Geodia globostellifera. J. Nat. Prod. 2001, 64, 813-815. [CrossRef] 
46. Meragelman, K.M.; McKee, T.C.; Boyd, M.R. New Cytotoxic Isomalabaricane Triterpenes from the Sponge Jaspis Species. J. Nat. Prod. 2001, 64, 389-392. [CrossRef]

47. Lv, F.; Deng, Z.; Li, J.; Fu, H.; van Soest, R.W.M.; Proksch, P.; Lin, W. Isomalabaricane-Type Compounds from the Marine Sponge Rhabdastrella aff. distincta. J. Nat. Prod. 2004, 67, 2033-2036. [CrossRef]

48. Lv, F.; Xu, M.; Deng, Z.; de Voogd, N.J.; van Soest, R.W.M.; Proksch, P.; Lin, W. Rhabdastrellins A-F, Isomalabaricane Triterpenes from the Marine Sponge Rhabdastrella aff. distincta. J. Nat. Prod. 2008, 71, 1738-1741. [CrossRef]

49. Tang, S.-A.; Deng, Z.-W.; Li, J.; Fu, H.-Z.; Pei, Y.-H.; Zhang, S.; Lin, W.-H. A New Isomalabaricane Triterpenoid from Sponge Jaspis sp. Chin. Chem. Lett. 2005, 16, 353-355.

50. Tang, S.; Pei, Y.; Fu, H.; Deng, Z.; Li, J.; Proksch, P.; Lin, W. Jaspolides A-F, Six New Isomalabricane-Type Terpenoids from the Sponge Jaspis sp. Chem. Pharm. Bull. 2006, 54, 4-8. [CrossRef]

51. Tang, S.; Deng, Z.; Proksch, P.; Lin, W. Jaspolides G and H, unique bisisomalabaricanes from the Chinese marine sponge Jaspis sp. Tetrahedron Lett. 2007, 48, 5443-5447. [CrossRef]

52. Clement, J.A.; Li, M.; Hecht, S.M.; Kingston, D.G.I. Bioactive Isomalabaricane Triterpenoids from Rhabdastrella globostellata that Stabilize the Binding of DNA Polymerase $\beta$ to DNA. J. Nat. Prod. 2006, 69, 373-376. [CrossRef] [PubMed]

53. Agrawal, M. Isolation and Structural Elucidation of Cytotoxic Agents from Marine Invertebrates and Plants Sourced from the Great Barrier Reef, Australia. Ph.D. Thesis, James Cook University, Douglas, Australia, 2007. Available online: http: / / researchonline.jcu.edu.au/2047/ (accessed on 13 February 2022).

54. Aoki, S.; Sanagawa, M.; Watanabe, Y.; Setiawan, A.; Arai, M.; Kobayashi, M. Novel isomarabarican triterpenes, exhibiting selective anti-proliferative activity against vascular endothelial cells, from marine sponge Rhabdastrella globostellata. Bioorg. Med. Chem. 2007, 15, 4818-4828. [CrossRef] [PubMed]

55. Hirashima, M.; Tsuda, K.; Hamada, T.; Okamura, H.; Furukawa, T.; Akiyama, S.-i.; Tajitsu, Y.; Ikeda, R.; Komatsu, M.; Doe, M.; et al. Cytotoxic Isomalabaricane Derivatives and a Monocyclic Triterpene Glycoside from the Sponge Rhabdastrella globostellata. J. Nat. Prod. 2010, 73, 1512-1518. [CrossRef]

56. Li, J.; Xu, B.; Cui, J.; Deng, Z.; de Voogd, N.J.; Proksch, P.; Lin, W. Globostelletins A-I, cytotoxic isomalabaricane derivatives from the marine sponge Rhabdastrella globostellata. Bioorg. Med. Chem. 2010, 18, 4639-4647. [CrossRef]

57. Li, J.; Zhu, H.; Ren, J.; Deng, Z.; Voogd, N.J.d.; Proksch, P.; Lin, W. Globostelletins J-S, isomalabaricanes with unusual cyclopentane sidechains from the marine sponge Rhabdastrella globostellata. Tetrahedron 2012, 68, 559-565. [CrossRef]

58. Xue, D.-Q.; Mao, S.-C.; Yu, X.-Q.; Guo, Y.-W. Isomalabaricane triterpenes with potent protein-tyrosine phosphatase 1B (PTP1B) inhibition from the Hainan sponge Stelletta sp. Biochem. Syst. Ecol. 2013, 49, 101-106. [CrossRef]

59. Xu, W.-g.; Wang, J.; Qiao, W.; Zhao, C.; Tang, S.-a. Jaspiferins H-J, New Isomalabaricane-Type Terpenoids from the South China Sea Marine Sponge Jaspis stellifera. Chem. Nat. Compd. 2018, 54, 84-87. [CrossRef]

60. Xu, W.-G.; Wang, J.; Xing, G.-S.; Xu, J.-J.; Qiao, W.; Zhao, C.; Tang, S.-A. Jaspiferin G, a new isomalabaricane-type triterpenoid from the sponge Jaspis stellifera. Z. Nat. C 2016, 71, 111. [CrossRef]

61. Li, Y.; Tang, H.; Tian, X.; Lin, H.; Wang, M.; Yao, M. Three new cytotoxic isomalabaricane triterpenes from the marine sponge Stelletta tenuis. Fitoterapia 2015, 106, 226-230. [CrossRef]

62. Kiem, P.V.; Dung, D.T.; Yen, P.H.; Nhiem, N.X.; Quang, T.H.; Tai, B.H.; Minh, C.V. New isomalabaricane analogues from the sponge Rhabdastrella providentiae and their cytotoxic activities. Phytochem. Lett. 2018, 26, 199-204. [CrossRef]

63. Dung, D.T.; Hang, D.T.T.; Nhiem, N.X.; Quang, T.H.; Tai, B.H.; Yen, P.H.; Hoai, N.T.; Thung, D.C.; Van Minh, C.; Van Kiem, P. Rhabdaprovidines D-G, Four New 6,6,5-Tricyclic Terpenoids from the Vietnamese Sponge Rhabdastrella providentiae. Nat. Prod. Commun. 2018, 13, 1934578X1801301004. [CrossRef]

64. Dung, D.T.; Yen, P.H.; Nhiem, N.X.; Quang, T.H.; Tai, B.H.; Van Minh, C.; Kim, D.C.; Oh, H.; Kim, Y.C.; Van Kiem, P. New Acetylated Terpenoids from Sponge Rhabdastrella providentiae Inhibit NO Production in LPS Stimulated BV2 Cells. Nat. Prod. Commun. 2018, 13, 1934578X1801300602. [CrossRef]

65. Kolesnikova, S.A.; Lyakhova, E.G.; Kozhushnaya, A.B.; Kalinovsky, A.I.; Berdyshev, D.V.; Popov, R.S.; Stonik, V.A. New Isomalabaricane-Derived Metabolites from a Stelletta sp. Marine Sponge. Molecules 2021, 26, 678. [CrossRef] [PubMed]

66. Trang, D.T.; Dung, D.T.; Nhiem, N.X.; Cuc, N.T.; Yen, P.H.; Hang, D.T.T.; Linh, T.M.; Mai, N.C.; Huong, P.T.T.; Tai, B.H.; et al. New tetracyclic and pentacyclic isomalabaricanes from the marine sponge Rhabdastrella globostellata (Carter, 1883). Tetrahedron Lett. 2022, 89, 153607. [CrossRef]

67. Sollas, W.J. Report on the Tetractinellida collected by H.M.S. Challenger, during the years 1873-1876. Report on the Scientific Results of the Voyage of H.M.S. Challenger, 1873-1876. Zoology 1888, 25, 1-458, pls I-XLIV.

68. Thiele, J. Studien über pazifische Spongien. I. Japanische Demospongien. Zool. Orig.-Abh. Aus Dem Gesamtgeb. Der Zool. Stuttg. 1898, 24, 1-72, pls I-VIII.

69. Sim, C.J. A taxonomic study on the marine sponges in Korea. 4. Choristida (Geodiidae). Korean J. Zool. 1982, 25, 1-8.

70. Lehnert, H.; Stone, R.P. A comprehensive inventory of the Gulf of Alaska sponge fauna with the description of two new species and geographic range extensions. Zootaxa 2016, 4144, 18. [CrossRef]

71. Theobald, N.; Wells, R.J.; Djerassi, C. Minor and trace sterols in marine invertebrates. 8. Isolation, structure elucidation, and partial synthesis of two novel sterols-stelliferasterol and isostelliferasterol. J. Am. Chem. Soc. 1978, 100, 7677-7684. [CrossRef]

72. Carballeira, N.; Thompson, J.E.; Ayanoglu, E.; Djerassi, C. Biosynthetic studies of marine lipids. 5. The biosynthesis of long-chain branched fatty acids in marine sponges. J. Org. Chem. 1986, 51, 2751-2756. [CrossRef] 
73. Li, Z.; Peng, C.; Shen, Y.; Miao, X.; Zhang, H.; Lin, H. 1,l-Diketopiperazines from Alcaligenes faecalis A72 associated with South China Sea sponge Stelletta tenuis. Biochem. Syst. Ecol. 2008, 36, 230-234. [CrossRef]

74. Huyen, V.T.T.; Minh, L.T.H.; Quyen, V.T.; Anh, N.M.; Cuc, N.T.K.; Luyen, N.T.; Dat, N.T. Antimicrobial metabolites from Streptomyces sp. strain PDH23 derived from marine sponge Rhabdastrella globostellata. Bangladesh J. Pharmacol. 2020, 15, 69-70. [CrossRef]

75. Khushi, S.; Salim, A.A.; Elbanna, A.H.; Nahar, L.; Capon, R.J. New from Old: Thorectandrin Alkaloids in a Southern Australian Marine Sponge, Thorectandra choanoides (CMB-01889). Mar. Drugs 2021, 19, 97. [CrossRef] [PubMed]

76. Tai, C.-J.; Huang, C.-Y.; Ahmed, A.F.; Orfali, R.S.; Alarif, W.M.; Huang, Y.M.; Wang, Y.-H.; Hwang, T.-L.; Sheu, J.-H. An AntiInflammatory 2,4-Cyclized-3,4-Secospongian Diterpenoid and Furanoterpene-Related Metabolites of a Marine Sponge Spongia sp. from the Red Sea. Mar. Drugs 2021, 19, 38. [CrossRef]

77. Yu, H.-B.; Gu, B.-B.; Iwasaki, A.; Jiang, W.-L.; Ecker, A.; Wang, S.-P.; Yang, F.; Lin, H.-W. Dactylospenes A-E, Sesterterpenes from the Marine Sponge Dactylospongia elegans. Mar. Drugs 2020, 18, 491. [CrossRef]

78. Abdjul, D.B.; Yagi, A.; Yamazaki, H.; Kirikoshi, R.; Takahashi, O.; Namikoshi, M.; Uchida, R. Anti-mycobacterial haliclonadiamine alkaloids from the Okinawan marine sponge Haliclona sp. collected at Iriomote Island. Phytochem. Lett. 2018, 26, 130-133. [CrossRef]

79. Kapojos, M.M.; Abdjul, D.B.; Yamazaki, H.; Kirikoshi, R.; Takahashi, O.; Rotinsulu, H.; Wewengkang, D.S.; Sumilat, D.A.; Ukai, K.; Namikoshi, M. Protein tyrosine phosphatase 1B inhibitory polybromobiphenyl ethers and monocyclofarnesol-type sesquiterpenes from the Indonesian marine sponge Lamellodysidea cf. herbacea. Phytochem. Lett. 2018, 24, 10-14. [CrossRef]

80. Salib, M.N.; Jamison, M.T.; Molinski, T.F. Bromo-spiroisoxazoline Alkaloids, Including an Isoserine Peptide, from the Caribbean Marine Sponge Aplysina lacunosa. J. Nat. Prod. 2020, 83, 1532-1540. [CrossRef]

81. Jiao, W.-H.; Li, J.; Wang, D.; Zhang, M.-M.; Liu, L.-Y.; Sun, F.; Li, J.-Y.; Capon, R.J.; Lin, H.-W. Cinerols, Nitrogenous Meroterpenoids from the Marine Sponge Dysidea cinerea. J. Nat. Prod. 2019, 82, 2586-2593. [CrossRef]

82. Bergquist, P.R. Shallow water Demospongiae from Heron Island. Univ. Qld. Pap. Great Barrier Reef Comm. Heron Isl. Res. Stn. 1969, 1, 62-72.

83. Schmitt, S.; Tsai, P.; Bell, J.; Fromont, J.; Ilan, M.; Lindquist, N.; Perez, T.; Rodrigo, A.; Schupp, P.J.; Vacelet, J.; et al. Assessing the complex sponge microbiota: Core, variable and species-specific bacterial communities in marine sponges. ISME J. 2012, 6, 564-576. [CrossRef] [PubMed]

84. Steinert, G.; Taylor, M.W.; Deines, P.; Simister, R.L.; de Voogd, N.J.; Hoggard, M.; Schupp, P.J. In four shallow and mesophotic tropical reef sponges from Guam the microbial community largely depends on host identity. PeerJ 2016, 4, e1936. [CrossRef] [PubMed]

85. Dat, T.T.H.; Steinert, G.; Thi Kim Cuc, N.; Smidt, H.; Sipkema, D. Archaeal and bacterial diversity and community composition from 18 phylogenetically divergent sponge species in Vietnam. PeerJ 2018, 6, e4970. [CrossRef]

86. Cho, J.H.; Djerassi, C. Minor and trace sterols from marine invertebrates. 58. Stereostructure and synthesis of new sponge sterols jaspisterol and isojaspisterol. J. Org. Chem. 1987, 52, 4517-4521. [CrossRef]

87. Zumberge, J.A.; Love, G.D.; Cárdenas, P.; Sperling, E.A.; Gunasekera, S.; Rohrssen, M.; Grosjean, E.; Grotzinger, J.P.; Summons, R.E. Demosponge steroid biomarker 26-methylstigmastane provides evidence for Neoproterozoic animals. Nat. Ecol. Evol. 2018, 2, 1709-1714. [CrossRef] [PubMed]

88. Cárdenas, P.; Pérez, T.; Boury-Esnault, N. Sponge Systematics facing new challenges. Adv. Mar. Biol. 2012, 61, 79-209. [PubMed]

89. Morrow, C.; Cárdenas, P. Proposal for a revised classification of the Demospongiae (Porifera). Front. Zool. 2015, 12, 1-27. [CrossRef]

90. Dohrmann, M.; Kelley, C.; Kelly, M.; Pisera, A.; Hooper, J.N.A.; Reiswig, H.M. An integrative systematic framework helps to reconstruct skeletal evolution of glass sponges (Porifera, Hexactinellida). Front. Zool. 2017, 14, 18. [CrossRef]

91. Voigt, O.; Wülfing, E.; Wörheide, G. Molecular Phylogenetic Evaluation of Classification and Scenarios of Character Evolution in Calcareous Sponges (Porifera, Class Calcarea). PLoS ONE 2012, 7, e33417. [CrossRef]

92. Alvizu, A.; Eilertsen, M.H.; Xavier, J.R.; Rapp, H.T. Increased taxon sampling provides new insights into the phylogeny and evolution of the subclass Calcaronea (Porifera, Calcarea). Org. Divers. Evol. 2018, 18, 279-290. [CrossRef]

93. Ruiz, C.; Muricy, G.; Lage, A.; Domingos, C.; Chenesseau, S.; Pérez, T. Descriptions of new sponge species and genus, including aspiculate Plakinidae, overturn the Homoscleromorpha classification. Zool. J. Linn. Soc. 2017, 179, 707-724. [CrossRef]

94. Li, Z.; He, L.; Miao, X. Cultivable Bacterial Community from South China Sea Sponge as Revealed by DGGE Fingerprinting and 16S rDNA Phylogenetic Analysis. Curr. Microbiol. 2007, 55, 465-472. [CrossRef]

95. Li, Z.-Y.; He, L.-M.; Wu, J.; Jiang, Q. Bacterial community diversity associated with four marine sponges from the South China Sea based on 16S rDNA-DGGE fingerprinting. J. Exp. Mar. Biol. Ecol. 2006, 329, 75-85. [CrossRef]

96. Lindgren, N.G. Beitrag zur Kenntniss der Spongienfauna des Malaiischen Archipels und der Chinesischen Meere Zool. Anz. 1897, $547,480-487$.

97. García-Ruiz, C.; Sarabia, F. Chemistry and Biology of Bengamides and Bengazoles, Bioactive Natural Products from Jaspis Sponges. Mar. Drugs 2014, 12, 1580. [CrossRef] [PubMed]

98. Wu, Q.; Nay, B.; Yang, M.; Ni, Y.; Wang, H.; Yao, L.; Li, X. Marine sponges of the genus Stelletta as promising drug sources: Chemical and biological aspects. Acta Pharm. Sin. B 2019, 9, 237-257. [CrossRef] 
99. Principe, P.P.; Fisher, W.S. Spatial Distribution of Collections Yielding Marine Natural Products. J. Nat. Prod. 2018, 81, 2307-2320. [CrossRef] [PubMed]

100. Schönberg, C.H.L. Who Is Who in Sponge Science 2021. World Porifera Database. 2021. Available online: http://www. marinespecies.org/porifera (accessed on 1 July 2021).

101. Russell, F.; Harmody, D.; McCarthy, P.J.; Pomponi, S.A.; Wright, A.E. Indolo[3,2-a]carbazoles from a Deep-Water Sponge of the Genus Asteropus. J. Nat. Prod. 2013, 76, 1989-1992. [CrossRef] 